\title{
Impact of combined hormonal therapy on coagulation inhibitory proteins
}

\author{
Eliana Ibrahimi ${ }^{1,2, *}$, Mynyr Koni $^{1}$ \\ ${ }^{1}$ Department of Biology, Faculty of Natural Science, University of Tirana, Tirana, Albania \\ 2 Ana Diagnostic Center, Tirana, Albania
}

\begin{abstract}
The objective of this study was to determine the effect of two combined oral contraceptives on two inhibitory coagulation proteins.

The study included 56 women between ages 20 and 55, twenty six of them taking $30 \mu \mathrm{g}$ ethinyloestradiol (EE) and $75 \mu \mathrm{g}$ gestodene (GSD) and thirty of them taking $30 \mu \mathrm{g}$ ethinyloestradiol and $75 \mu \mathrm{g}$ levonogestrel (LNG) for two months. The subjects were healthy and they had not taken any other drug two months before starting the hormonal therapy. Plasma was used for measuring protein C and antithrombin III (AT III), before using the pill and after stopping it.

Comparison of the values of protein C and AT III between two periods (before and after treatment) showed the following results: Concentrations of protein $\mathrm{C}$ was significantly increased while AT III level was decreased after treatment with $30 \mu \mathrm{g}$ EE/ $75 \mu \mathrm{g}$ GSD ( $\mathrm{p}=0.001)$. Treatment with $30 \mu \mathrm{g}$ EE/ $75 \mu \mathrm{g}$ LNG showed no significant change in the level of AT III $(\mathrm{p}=0.058)$ and significantly increased protein $\mathrm{C}$ concentration $(\mathrm{p}=0.001)$.

We conclude that treatment with $30 \mu \mathrm{g}$ EE/ $75 \mu \mathrm{g}$ GSD induces more changes in the inhibitory coagulation proteins than treatment with $30 \mu \mathrm{g}$ EE/ $75 \mu \mathrm{g} \mathrm{LNG}$, indicating an increased risk for thrombotic diseases.
\end{abstract}

Key Words: Combined hormonal therapy, protein C, antithrombin III, thrombosis risk

\section{Introduction}

Epidemiologic studies published in 1995 reported a slightly higher risk of venous thromboembolism among users of oral contraceptives (OCs) containing desogestrel or gestodene as the progestogenic component (third generation OCs) as than among users of OCs containing levonorgestrel or norgestimate as the progestogenic component (second-generation OCs $(1,2)$.

Oral oestrogen use in women has been associated with increased risk of venous thromboembolism. In premenopausal women, the risk of venous thromboembolism has been shown to increase by about two to six-fold during the use of combined oral contraceptives, (3).

Due to the observed differences in the risk of VT induced by OC containing the same dose of estrogen but different progestogen compounds, the prothrombotic effect of the pill was considered to be not strictly dependent on the dose of estrogen but rather on the "total estrogenicity" of the formulation (4). The "total estrogenicity" rises with increasing dose of estrogen but decreases with increasing antiestrogenic activity of progestogen compound. It was suggested that third generation progestogens, as well as drospirenone and cyproterone acetate possess a weaker anti-estrogenic activity than levonorgestrel and, therefore, are less potent in the counterbalancing the prothrombotic effects of estrogen $(4,5)$. Consequently, OC containing third generation progestogens (desogestrel or gestodene), drospirenone or cyproterone acetate have a higher "total estrogenicity" as compared to second generation OC which may explain why users of these formulations are exposed to a higher thrombotic risk (5).

Heritable thrombophilia is another thrombotic factor that include deficiencies of antithrombin, protein $\mathrm{C}$ and protein $\mathrm{S}$; and common genetic mutations such as factor V Leiden and the prothrombin G20210A mutation (6). Other relatively common thrombophilias with a combination of heritable and acquired components include elevated plasma factor VIIIc (7), hyperhomocysteinaemia (8) and acquired activated protein $\mathrm{C}$ resistance (9).

The further increased thrombotic risk in third generation OC users was, however, questioned in later publications $(10,11,12)$. The discussion that followed was hampered by the fact that there was 
neither a good biological explanation for the thrombotic effect of the pill nor for the difference between second and third generation oral contraceptives (13).

Therefore the aim of this study was to determine the effect of two combined oral contraceptives (containing: ethinylestradiol/levonogestrel and ethinylestradiol/ gestodene) on protein C and antithrombin III concentrations in a group of healthy Albanian women.

\section{Material and methods}

Study design: The study was carried out at Ana Diagnostic Center, in Tirana, Albania. Healthy women requesting contraception were included and followed up for two months. Twenty six women were instructed to use COC with $30 \mu \mathrm{g}$ EE and $75 \mu \mathrm{g}$ GSD and thirty were instructed to use COC with $30 \mu \mathrm{g}$ EE and $75 \mu \mathrm{g} \mathrm{LNG}$, initiating pill intake on the first day of the cycle. Clinical and laboratory assessments were carried out prior to initiation of medication (pretreatment) and after 2 months of COC use.

Laboratory methods: All participants were submitted to a blood collection to perform the antithrombin III and protein C laboratory test. Blood samples were centrifuged at $1500 \mathrm{rev} / \mathrm{min}$ for $15 \mathrm{~min}$ to extract plasma. We used chromogenic assay (Cobas 6000, Roche) to evaluate antithrombin III while protein $\mathrm{C}$ was evaluated via ELFA (Vidas, Biomerieux).

Statistical analyses: Student's t-test for paired samples was used for numerical variables to compare levels of inhibitory coagulation proteins at two time intervals (pre-treatment and after 2 months of COCs use). Statistical significance $(\mathrm{p}<0.05)$ was determined using SPSS 20 software.

\section{Results}

Comparison of the values of protein C and AT III between two periods (before and after treatment) showed the following results: concentrations of protein $C$ was significantly increased $(p=0.001)$ while AT III level was reduced after treatment with $30 \mu \mathrm{g}$ $\mathrm{EE} / 75 \mu \mathrm{g}$ GSD $(\mathrm{p}=0.001)$. Treatment with $30 \mu \mathrm{g}$ $\mathrm{EE} / 75 \mu \mathrm{g}$ LNG showed no significant change in the level of AT III $(p=0.058)$ and significantly increased protein C concentration ( $\mathrm{p}=0.001)$, (Table. 1). Statistical analysis indicated no significant difference in the effect of different COCs on the level of PC $(p=0.36)$ and a different effect on AT III level $(p=0.017)$ (Table 2). Correlation between parameters (antithrombin III and protein C) before and after treatments was not significant. After treatment with $30 \mu \mathrm{g}$ EE $/ 75 \mu \mathrm{g}$ GSD between AT III and PC, Pearson correlation $\mathrm{r}=0.248, \mathrm{p}=0.065$; after treatment with $30 \mu \mathrm{g}$ EE $/ 75 \mu \mathrm{g}$ LNG, Pearson correlation $\mathrm{r}=0.274 ; \mathrm{p}=0.143$.

\section{Discussions}

This study showed that use of combined oral contraceptives leads to significant changes in protein $\mathrm{C}$ and antithrombin III plasma concentrations. The investigation found a large effect of oestrogen and progestogen on protein C. A greater change but not significant in protein $C$ level was observed in the GSD group compared with the LNG group. Comparison between treatments reported the same effect on protein C concentration $(p=0.36$; table 2$)$. Our results of a rise in protein $\mathrm{C}$ activity during use of both formulations confirm those of previous OC studies $(12,14,15)$.

Table 1. Effects of COCs on protein $\mathrm{C}$ and antithrombin III

\begin{tabular}{lcccccc}
\hline \multirow{2}{*}{ Parameters } & \multicolumn{3}{c}{$30 \mu \mathrm{g}$ EE $/ 75 \mu \mathrm{g}$ GSD } & \multicolumn{3}{c}{$30 \mu \mathrm{g}$ EE/75 $\mu \mathrm{g}$ LNG } \\
\cline { 2 - 7 } & Baseline & COC use & p-value & Baseline & COC use & p-value \\
\hline Antithrombin III & 96.215 & 91.161 & 0.001 & 103.9 & 98.6 & $0.058^{\text {ns }}$ \\
$(\%)$ & \pm 1.77 & \pm 1.72 & & \pm 1.4 & \pm 2.0 & \\
\hline Protein C & 117.2 & 131.8 & 0.001 & 115.5 & 128.6 & 0.001 \\
$(\%)$ & \pm 1.86 & \pm 5.0 & & \pm 2.5 & \pm 1.84 & \\
\hline
\end{tabular}

Table 2. Comparison between different COC effects on protein $\mathrm{C}$ and antithrombin III; estimated mean difference (EMD)a , 95\% confidence interval (CI) and $p$-value

\begin{tabular}{lcccccc}
\hline \multirow{2}{*}{ Comparison } & \multicolumn{3}{c}{ Antithrombin III } & \multicolumn{3}{c}{ Protein C } \\
\cline { 2 - 7 } & EMD & $95 \%$ CI & p & EMD & $95 \%$ CI & p \\
\hline $30 \mathrm{EE} / 75$ GSD vs 30 EE/75 LNG & -8.2 & $-14.7,-1.6$ & 0.017 & 5.5 & $-6.7-17.7$ & 0.36 \\
\hline
\end{tabular}

${ }^{a}$, results of analysis of paired samples $t$-test 
Antithrombin III activity was significantly reduced during treatment with combination containing 30 $\mu \mathrm{g} \mathrm{EE} / 75 \mu \mathrm{g}$ GSD ( $\mathrm{p}=0.001$; table 1). The results agree with those of several studies with various low-dose formulations that have revealed no change or only a slight decrease in antithrombin III activity (14-16). Combination containing EE and second generation LNG had no significant effect on AT III concentrations $(\mathrm{p}=0.058$; table $1)$, this means that treatments hadn't the same effect on AT III ( $p=0.017$; table 2). Differences in the effect of second generation COCs and third generation COCs are also reported from recent studies (17). OC use causes considerable alterations in the anticoagulant system (Table 1), decreasing the plasma level of the major inhibitor of several activated coagulation factors, antithrombin III (17). Pronounced changes occur also in the protein $\mathrm{C}$ pathway. OC induce a small increase in the concentration and activity of protein $\mathrm{C}$, which is reported to be counterbalanced by elevated levels of the major protein $\mathrm{C}$ inhibitors, i.e. protein $\mathrm{C}$ inhibitor, $\alpha 1$ antitrypsin $(\alpha 1$-antiprotease $)$ and $\alpha 2$ macroglobulin (5).

Based on our results we conclude that the use of a COCs containing $30 \mu \mathrm{g}$ EE/75 $\mu \mathrm{g}$ GSD for a period of two months in healthy women with no associated risk factors caused significant changes in protein $\mathrm{C}$ and AT III levels. Treatment with 30 $\mu \mathrm{g}$ EE/75 $\mu \mathrm{g}$ LNG showed no significant change in AT III plasma concentration and significantly increased protein $\mathrm{C}$ level. The clinical significance of these findings should be evaluated in a larger cohort study.

Acknowledgments: The authors are grateful to Faculty of Natural Sciences, University of Tirana, and staff of "Ana Diagnostic Center" laboratory and clinic, for providing the financial support and necessities for this study

\section{References}

1. World Health Organization. World Health Organization Collaborative Study of Cardiovascular Disease and Steroid Hormone Contraception: Effect of different progestagens in low oestrogen oral contraceptives on venous thromboembolic disease. Lancet 1995; 346: 1582-1588.

2. Jick H, Jick SS, Gurewich V, Myers MW, Vasilakis C. Risk of idiopathic cardiovascular death and nonfatal venous thromboembolism in women using oral contraceptives with differing progestagen components. Lancet 1995; 346: 1589-1593.

3. Rosendaal FR, Van Hylckama Vlieg A, Tanis BC, Helmerhorst FM. Estrogens, progestogens and thrombosis. J Thromb Haemost 2003; 1: 13711380 .

4. Odlind V, Milsom I, Persson I, Victor A. Can changes in sex hormone binding globulin predict the risk of venous thromboembolism with combined oral contraceptive pills? Acta Obstet Gynecol Scand 2002; 81: 482-490.

5. Kemmeren JM, Algra A, Meijers JC, et al. Effect of second- and third-generation oral contraceptives on the protein $\mathrm{C}$ system in the absence or presence of the factor VLeiden mutation: a randomized trial. Blood 2004; 103: 927-933.

6. Walker ID, Greaves M, Preston FE. On behalf of the Haemostasis and Thrombosis Task Force British Committee for Standards in Haematology. Investigation and management of heritable thrombophilia Br J Haematol 2001; 114: 512-528.

7. Koster T, Blann AD, Briët E, Vandenbroucke JP, Rosendaal FR. Role of clotting factor VIII in effect of von Willebrand factor on occurrence of deepvein thrombosis. Lancet 1995; 345: 152-155.

8. den Heijer M, Koster T, Blom HJ, et al. Hyperhomocysteinemia as a risk factor for deepvein thrombosis. N Engl J Med 1996; 334: 759-762.

9. Clark P, Walker ID. The phenomenon known as acquired activated protein $\mathrm{C}$ resistance. $\mathrm{Br} \mathrm{J}$ Haematol 2001; 115: 767-773.

10. Baillargeon JP, McClish DK, Essah PA, Nestler JE. Association between the current use of low-dose oral contraceptives and cardiovascular arterial disease: a meta-analysis. J Clin Endocrinol Metab 2005; 90: 3863-3870.

11. van Hylckama Vlieg A, Helmerhorst FM, Vandenbroucke JP, Doggen CJ, Rosendaal FR. The venous thrombotic risk of oral contraceptives, effects of oestrogen dose and progestogen type: results of the MEGA case-control study. BMJ 2009; 339: 2921.

12. Parkin L, Sharples K, Hernandez RK, Jick SS. Risk of venous thromboembolism in users of oral contraceptives containing drospirenone or levonorgestrel: nested case-control study based on UK General Practice Research Database. BMJ 2011; 342: d2139.

13. Lidegaard $\varnothing$, Løkkegaard E, Svendsen AL, Agger C. Hormonal contraception and risk of venous thromboembolism: national follow-up study. BMJ 2009; 339: b2890.

14. Spona J, Feichtinger W, Kindermann C, et al. Double-blind, randomized, placebo controlled study on the effects of the monophasic oral contraceptive containing 30 micrograms ethinyl estradiol and 2.00 $\mathrm{mg}$ dienogest on the hemostatic system. Contraception 1997; 56: 67-75.

15. J Jespersen KR, Petersen SO. Skouby Coagulation and fibrinolysis comparison study of two new lowdose oral contraceptives Adv Contraception, 7 1991; pp. 292-296.

16. Winkler UH, Daume E, Sudik R, et al. A comparative study of the hemostatic effects of two monophasic oral contraceptives containing 30

East J Med Volume:21, Number:1, January-March/2016 
$\mathrm{mu}(\mathrm{g})$ ethinylestradiol and either $2 \mathrm{mg}$ chlormadinone acetate or $150 \mathrm{mu}(\mathrm{g})$ desogestrel. Eur J Contracept Reprod Health Care 1999; 4: 145154.
17. Tans G, Curvers J, Middeldorp S, et al. A randomized cross-over study on the effects of levonorgestrel- and desogestrel-containing oral contraceptives on the anticoagulant pathways. Thromb Haemost 2000; 84: 15-21.

East J Med Volume:21, Number:1, January-March/2016 